\title{
Pengembangan Bantaran Citarum
}

Gede H. Cahyana, Tri Mulyani, Amalia Rosalina, Irma Ismayani

Prodi Teknik Lingkungan Universitas Kebangsaan, Bandung

HU Pikiran Rakyat, Juni 2016

Dua tahun berselang sejak program Ecovillage dirilis oleh Pemerintah Provinsi Jawa Barat pada 22 Juni 2014 di Desa Majasetra, Kecamatan Majalaya, Kabupaten Bandung. Realisasi program ini sudah menumbuhkan tak kurang dari 120 Ecovillage demi mewujudkan Citarum Bersih, Sehat, Lestari (Bestari). Betapa tidak, Citarum adalah sungai yang melewati duabelas kabupaten /kota di Jawa Barat. Hulunya di lereng Gunung Wayang, Cisanti Kabupaten Bandung dan hilirnya di Muara Gembong, Kabupaten Bekasi.

Dengan panjang kurang-lebih $280 \mathrm{~km}$, Citarum menjadi sumber air minum, irigasi, perikanan, peternakan, industri, dan kebutuhan perkotaan masyarakat di kabupaten/kota tersebut. Bahkan Provinsi DKI Jakarta pun memperoleh sebagian sumber air bakunya dari Citarum. Karena kualitas airnya yang kotor atau dicemari oleh limbah domestik, industri, peternakan, perkebunan, persawahan, maka air Sungai Citarum tidak bisa langsung diminum, bahkan tidak layak digunakan untuk mencuci beras, ikan, dan sayurmayur. Padahal sungai inilah yang potensial dijadikan sumber air oleh masyarakat di dekat badan air ini, baik sebagai air untuk MCK maupun air minum dan keperluan industri makanan dan minuman.

\section{Kondisi Eksisting}

Semua PDAM termasuk PAM Jaya di Jakarta yang memanfaatkan air Sungai Citarum sebagai air baku mengolah air sungai ini dengan teknologi pengolahan lengkap (complete treatment). Biaya operasi dan perawatannya relatif mahal, misalnya untuk biaya energi pompa, blower aerator, zat kimia seperti tawas, kaporit, gas klor, penetral derajat keasaman $(\mathrm{pH})$ dan listrik. Teknologi skala besar ini tentu tidak layak secara ekonomi apabila diterapkan di masyarakat perdesaan khususnya yang tinggal di dekat bantaran Citarum dengan usaha semacam warung makan, toko, dan industri kecil di daerah tujuan wisata dekat badan air Citarum ini. Oleh sebab itu, perlu diujicobakan teknologi yang sederhana untuk mengolah air Sungai Citarum dalam skala kecil dan 
mikro yang disebut gugus. Gugus pengolahan ini bisa dibangun di banyak titik (lokasi) di sepanjang alur DAS Citarum, terutama di daerah tujuan wisata dan pusat-pusat perdagangan dan industri kecil milik masyarakat.

Gugus pengolahan air ini terdiri atas variasi filter kasar (roughing filter) dan modifikasi filter pasir lambat (slow sand filter) yang disebut Gugus Filter Multitahap (Gutertap). Untuk menghasilkan air olahan yang diinginkan, air Sungai Citarum diolah dalam tiga tahap. Tahap pertama, air Citarum diolah menjadi air yang layak digunakan untuk keperluan menyiram taman bunga dan tanah. Yang kedua air olahan yang layak untuk keperluan MCK, bebersih lantai, air wudhu. Yang ketiga adalah air yang layak diminum langsung tanpa direbus dulu. Diharapkan air olahan gugus ini bisa bebas bakteri.

\section{Sejarah Gutertap}

Sampai saat ini belum ada Gugus Filter Multitahap (Gutertap) yang diterapkan oleh PDAM di Indonesia. Mayoritas PDAM menggunakan unit prasedimentasi sebagai praolah. PDAM Kota Bandung sebagai contoh, di dekat lokasi intake di Sungai Citarum, memanfaatkan prased untuk menurunkan kekeruhan sebelum airnya dialirkan ke Badaksinga sejauh $32 \mathrm{~km}$. Bisa dimaklumi karena pembangunan unit ini dilaksanakan sebelum studi intensif Filter Multitahap dibuat. Filter ini mulai intensif diteliti pada satu dekade terakhir abad ke-20 di Amerika Latin oleh IRC-CINARA (International Water and Sanitation Centre - Instituto de Investigacion y Desarollo en Abastecimiento de Agua) di Colombia.

Pada risetnya, CINARA membuat pilot plant dengan variasi beberapa unit operasi di Puerto Mallarino. Air bakunya berasal dari sungai dengan kekeruhan antara 80 s.d 3.600 NTU. Airnya sangat tercemar dengan rerata kandungan bakteri coliform 63.000 Colony Forming Unit (CFU) dan maksimum 500.000 CFU. Hasil pengolahan dengan Gutertap bisa mencapai 3 - 24 NTU dari air yang sangat keruh tanpa perlu zat kimia (koagulan). Bagaimana ini bisa terjadi? Ternyata ini terjadi karena teknologi yang mereka sebut Multistage Filtration (Filtrasi Multitahap). Variasi dan susunannya cukup banyak, dimulai dari intake, dynamic gravel filter, upflow gravel filter in layers and series, downflow gravel filter in layers and series, horizontal gravel filter, dan slow sand filter.

Media yang digunakan untuk pengisi Gutertap adalah kerikil yang diperoleh dari daerah setempat dengan ukuran $0,5-3 \mathrm{~cm}$. Berat jenis batu ini antara 2,6 - 3,0. Yang 
digunakan adalah batu yang relatif bulat atau lonjong, berupa batuan beku. Kalau di lokasi tidak ada batuan tersebut, maka bisa digunakan batu pecah yang biasa digunakan untuk perkerasan jalan dengan ukuran yang mendekati ukuran yang disyaratkan. Gutertap sangat fleksibel dalam terapannya di lapangan. Sebagai gambaran, konfigurasi unit seperti tampak pada Gambar 1.

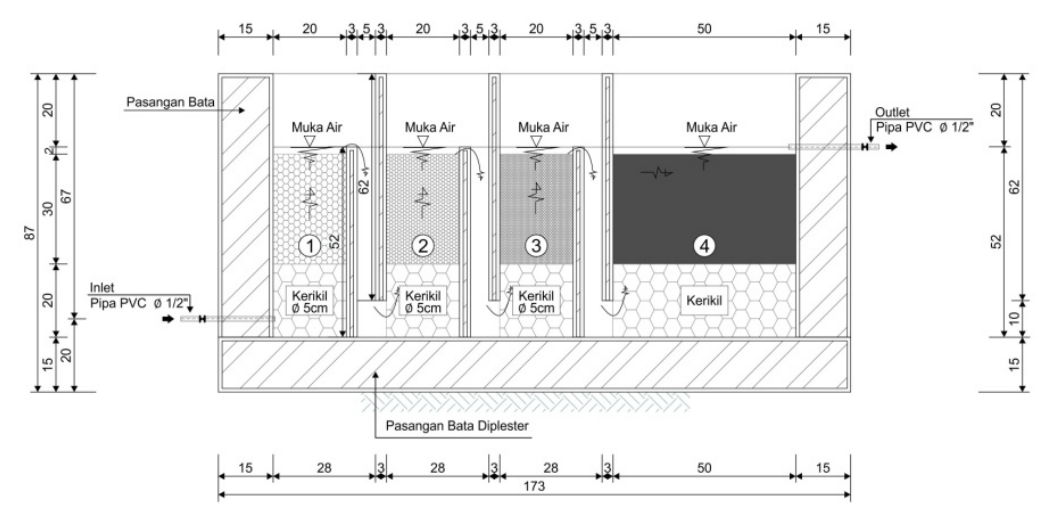

Gambar 1. Gambar IPAM Gutertap yang diterapkan di Citarum

\section{Manfaat dan Peran Masyarakat}

Pembangunan unit percontohan Gutertap ini dilaksanakan di Desa Bojongsari, Kecamatan Bojongsoang, Kabupaten Bandung. Masyarakat ikut berperan dalam pembangunan dan menjaga keamanan instalasi dari bahaya banjir. Seperti tempak pada Gambar 2 (foto terlampir), air Citarum dengan kekeruhan hingga 1.200 NTU bisa diolah menjadi 25 NTU. Efisiensinya sekitar 98\%. Dengan kejernihan ini, maka potensi untuk menjadikan air Citarum sebagai air layak minum masih terbuka lebar. Adapun wujud instalasi Gutertap dapat dilihat pada Gambar 3.

Masih dalam upaya menuju Citarum Bestari, bersamaan dengan rangkaian kegiatan untuk memperingati Hari Lingkungan Dunia (5 Juni 2016), maka dilaksanakan tatap muka dengan warga setempat di kantor Desa Bojongsari, dihadiri oleh Kepala Desa dan jajarannya serta perwakilan masyarakat, termasuk pegiat Ecovillage di tepian Citarum. Tanggapan positif dari hadirin menandakan bahwa program peningkatan kualitas air 
Sungai Citarum sangat diharapkan, tidak hanya untuk keperluan air MCK dan minum, tetapi juga untuk perikanan dan pertanian.

Bentuk kepedulian warga tepian Citarum berdampak pada raihan manfaat Citarum untuk masa depan, dengan target tahun 2018, seperti yang dicanangkan oleh Pemerintah Provinsi Jawa Barat. Gutertap juga memberikan opsi bagi pengembangan Ecovillage di bantaran Citarum dalam berbagai ragam kegiatannya, mulai dari pertanian, perikanan, perdagangan, hingga industri kecil. Manfaat lainnya adalah memberikan alternatif pengolahan air Sungai Citarum sehingga mampu mencapai Citarum Bestari. Selain itu, juga memiliki manfaat praktis dalam skala lapangan yakni suatu model pengolahan air alternatif, sebuah teknologi yang jarang diterapkan di PDAM. *

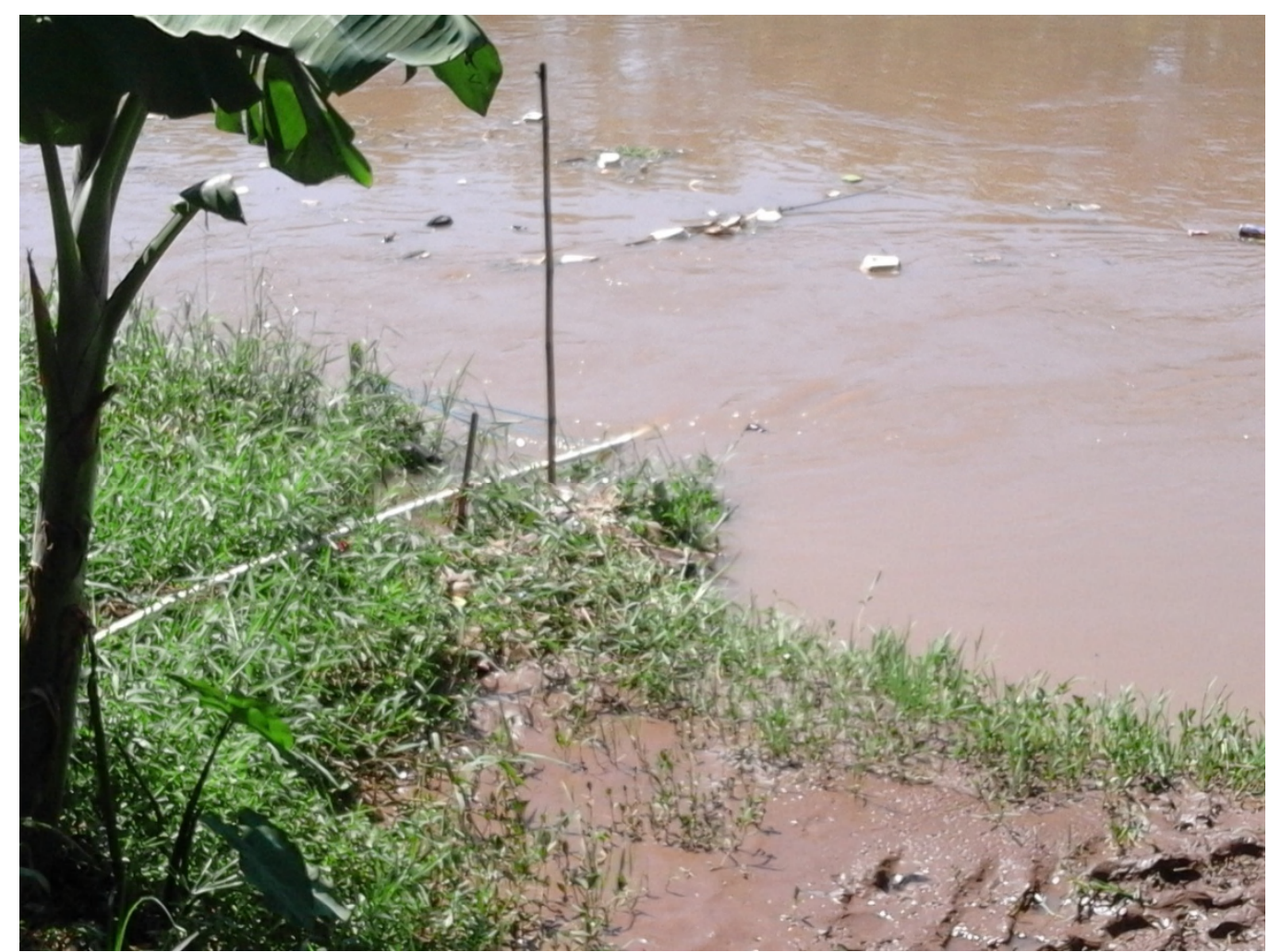

Gambar 2. Air Sungai Citarum yang sangat keruh. 


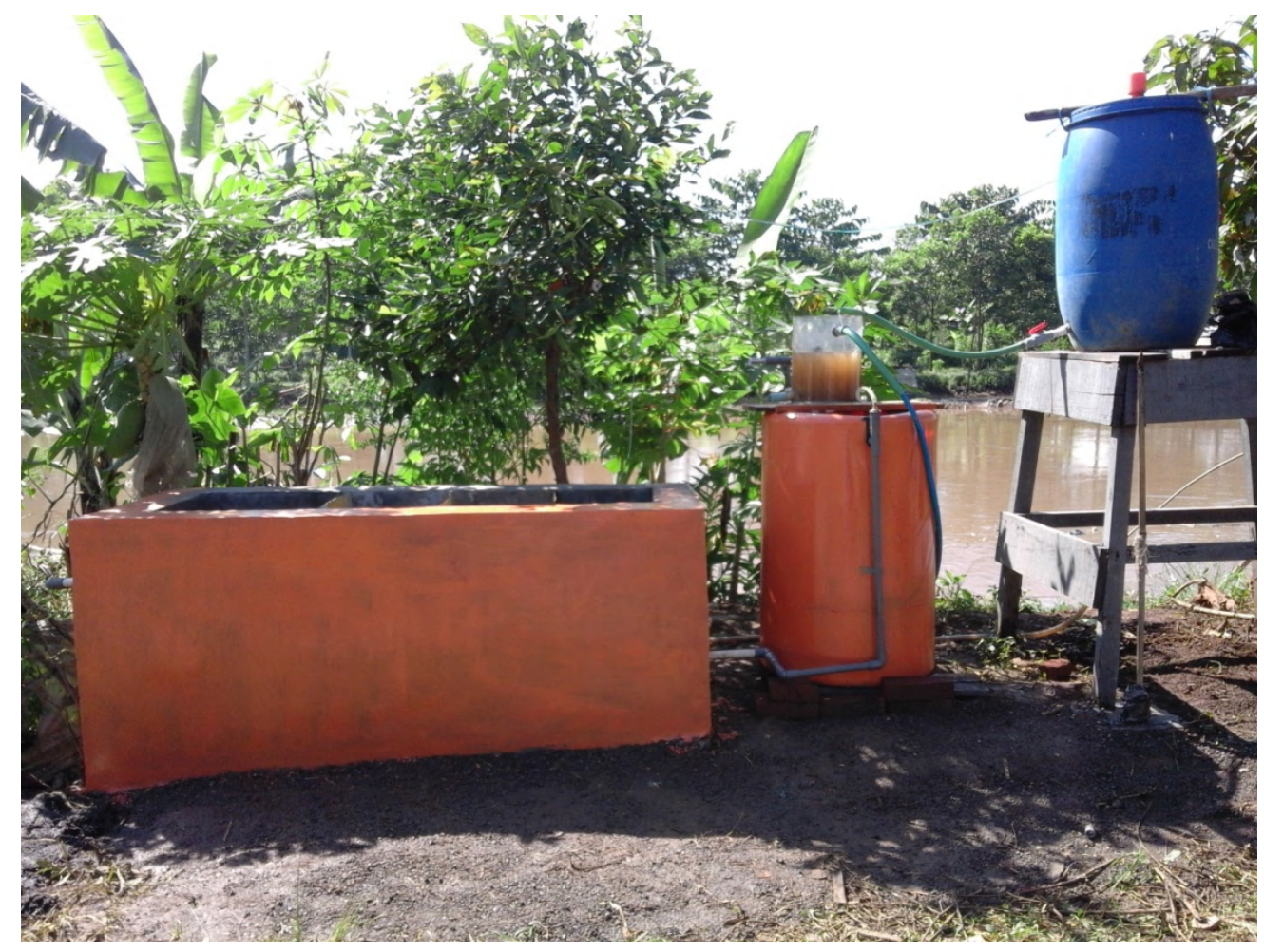

Gambar 3. Instalasi Gutertap di Desa Bojongsari, tepian Citarum. 